\title{
Effectiveness of blower and HVLS fan in feedlot to performans of brahman, belmont red and charolais cattle
}

\author{
David Isaac Yasin, Ma'ruf Tafsin*, and Simon P Ginting \\ Agricultural Faculty, Universitas Sumatera Utara
}

\begin{abstract}
The purpose of this study is to determine the impact of heat stress on Brahman Cross cattle performance which is maintained by feedlot with three treatments (non using fan, blower fan and HVLS fan) using split plot design, Giving the fan is treated as the main plot factor, while the cattle is treated as a plot factor factor (sub plot factor). Knowing the financial value of each treatment: feed consumption, daily weight gain, feed conversion, feed cost, cost per gain of Brahman, Belmont red and Charolais is fattened in feedlot. The result showed that using HVLS fan is most effective to cattle performance than blower fan and non using fan for belmont red and charolais cattle.
\end{abstract}

\section{Introduction}

Indonesia is one of the countries with very high meat needs, the average annual requirement in Indonesia reaches 3.5 million head or equivalent to 680,000 tons per year which can be fulfilled by local supply about $54 \%$ of total requirement, so that the government grants import permits in the effort to fulfill the national meat requirement in the form of meat and beef, almost $100 \%$ of imported cattle are from Australia. The age of cattle imported to Indonesia is 1.5 years to 3 years with an average weight of about $250 \mathrm{~kg}$ to $340 \mathrm{~kg}$. Cattle imported to Indonesia are delivered by ship with a comfortable design for cattles, a long journey from Australia to Indonesia between 5-10 days of travel.

Imported cattle imports from abroad are entirely private, and intensive feedlot feed for three to four months. Cattle imported into Indonesia is a brahman cross (BX) cattle species originally from Australia, there are many types of Brahman cross cattle from Australia crossed with the nation of cows with superior genetics, especially European beef cattle (Bos Taurus). The type of cattle that is commonly sent to Indonesia from Australia, $75 \%$ is brahman cattle genetic that has been crossed with European and American cattles, while $25 \%$ are European cattle that are kept in cold areas (southern Australia) and almost all cows are delivered to Indonesia is a brahman crosses cattle. Constraints faced by feedlotter usually is if they get cattle from the south (cold areas) that temperature between $\left(6^{\circ} \mathrm{C}\right.$ to $18^{\circ} \mathrm{C}$ ) not from the north or west of a temperature that is similar to the temperature of the tropics $\left(21^{\circ} \mathrm{C}\right.$ to $\left.32^{\circ} \mathrm{C}\right)$ with an average humidity of $60 \%$. These obstacles include respiratory disease due to overheated cattles (average temperature $32^{\circ} \mathrm{C}$ ) and high

* Correspondent Author: martafsin@yahoo.com

(C) The Authors, published by EDP Sciences. This is an open access article distributed under the terms of the Creative Commons Attribution License 4.0 (http://creativecommons.org/licenses/by/4.0/). 
humidity reaches $80 \%$ on average, this greatly affects the productivity of cattle that we will keep. Another case if we sent cattles from northern Australia or western Australia cattles are usually already resistant to the temperature in Indonesia, because there has been a cross with brahman cattles that have proven resistant to hot temperatures.

There are four elements of microclimate that can directly affect the productivity of livestock, namely: temperature, air humidity, radiation and wind speed, while the other two elements of evaporation and precipitation affect indirect livestock productivity. Temperature and air humidity are two climate factors that affect cattle production, because it can cause changes in heat balance in the body of cattle, water balance, energy balance and balance of livestock behavior [1]. Life and production in livestock require optimum environmental temperature Robert E.[2]. Comfortable temperature thermonetral zone for European cattle ranges from $13-18^{\circ} \mathrm{C}$ [3]; $4-25^{\circ} \mathrm{C}[4], 5-25^{\circ} \mathrm{C}$. Daily air and humidity in Indonesia are generally high, ranging from $24-34^{\circ} \mathrm{C}$ and $60-90 \%$ humidity. This will greatly affect the level of cattle productivity. At these temperatures and moisture, the evaporation process of the cattle's body will be inhibited so as to experience heat stress. The effects of cattle due to heat stress are decreased appetite, increased consumption of drinking, decreased metabolism and increased catabolism, increased heat release through evaporation, decreased blood hormone concentration, increased body temperature, respiration and heart rate [5] and changes behavior [6], increased intensity of shelter. Environmental modification is necessary if there are genetically dominant cattles of European cattle, such as; Angus, Charolais and Belmont red, although the cattle are all completely crossed with Brahman cattles. Modified environments necessary to optimize the growth of the cattle. One of the success factors of cattle feedlot is optimization of sheed management, including sheed design and maintenance support facility. In the feedlot sheed management one of the optimization management of the sheed is by the addition of a fan, can be a blower or a hanging large fan or often called HVLS fan (High Volume Low Speed). The purpose of the fan usage is to lower the room temperature and speed up the release rate of ammonia in the sheed, thus making the cattle feel comfortable especially for the cattle that come from cold regions (south Australia). So far there has not been much research literature on cattle maintenance in feedlot using fan, so it is necessary to do research to know the effectiveness of different fan usage

\section{Materials and Methods}

The cattle used in this study were 15 Brahman steers ,15 Charbray / Charbrah steerers and 15 Belmont Red steerers with an initial body weight of $310 \pm 10 \mathrm{~kg}$ were used in this study. Gang way connected with cattle crush, individual scale digital cattle brand True Test, a computer unit, the sit scales. This research was conducted for \pm 4 months starting from November 2017 until February 2018 at Fattening Feedlot PT. Juang Jaya Abdi Alam, Deli Serdang District, Noth Sumatera.

The design used in this study is the Design Split plot Design. This design is used for experiments intended to investigate major influences and interactions with unequal degrees of accuracy. Giving the fan is treated as the main plot factor, while the cattle is treated as a plot factor factor (sub plot factor). Place of experiment divided into block, number of replication. The division of the block is in accordance with the principle of local control. Each block is divided into main plot (PU). The amount of PU in each block is the same as the type of treatment. The placement of treatment into PU is done randomly, and coded according to the treatment given.

\section{Results and Discussion}


Table. 1 Influence of fan and cattle breed on performance during maintenance period

\begin{tabular}{|c|c|c|c|c|}
\hline \multirow[t]{2}{*}{ Cattle breed } & \multicolumn{3}{|c|}{ Type of fan } & \multirow[t]{2}{*}{ Average \pm SD } \\
\hline & Control & Blower & HVLS & \\
\hline \multicolumn{5}{|c|}{ 1. Consumption (Kg/head/day) } \\
\hline Brahman & 13,66 & 13,86 & 13,68 & $13.73^{\mathrm{a}} \pm 0,11$ \\
\hline Belmont Red & 13,26 & 13,40 & 13,78 & $13.48^{\mathrm{b}} \pm 0,27$ \\
\hline Charolais & 13,78 & 13,82 & 13,82 & $13.81^{\mathrm{a}} \pm 0,02$ \\
\hline Average \pm SD & $113.57^{\mathrm{a}} \pm 0,27$ & $13.69^{\mathrm{a}} \pm 0,25$ & $13.76^{\mathrm{a}} \pm 0,07$ & \\
\hline \multicolumn{5}{|c|}{ 2. ADG (Kg/head/day) } \\
\hline Brahman & 1,85 & 1,81 & 1,80 & $1.82^{\mathrm{a}} \pm 0,03$ \\
\hline Belmont Red & 1,67 & 1,86 & 2,04 & $1.86^{\mathrm{a}} \pm 0,19$ \\
\hline Charolais & 1,71 & 1,87 & 2,04 & $1.87^{\mathrm{a}} \pm 0,17$ \\
\hline Average $\pm \mathrm{SD}$ & $1.74^{\mathrm{c}} \pm 0,095$ & $1.85^{\mathrm{b}} \pm 0,032$ & $1.96^{\mathrm{a}} \pm 0,139$ & \\
\hline \multicolumn{5}{|l|}{ 3. FCR } \\
\hline Brahman & 7,42 & 7,71 & 7,62 & $7.58^{a} \pm 0,15$ \\
\hline Belmont Red & 7,98 & 7,24 & 6,77 & $7.33^{a} \pm 0,61$ \\
\hline Charolais & 8,11 & 7,39 & 6,77 & $7.43^{a} \pm 0,67$ \\
\hline Average \pm SD & $7.84^{\mathrm{a}} \pm 0,37$ & $7.45^{\mathrm{ab}} \pm 0,24$ & $7.05^{\mathrm{b}} \pm 0,49$ & \\
\hline \multicolumn{5}{|c|}{ 4. Feed cost (IDR/Head/day) } \\
\hline Brahman & 31.418 & 31.878 & 31.464 & $31.586 .67^{\mathrm{a}} \pm 253,35$ \\
\hline Belmont Red & 30.498 & 30.820 & 31.694 & $31.004 .00^{\mathrm{b}} \pm 618,87$ \\
\hline Charolais & 31.694 & 31.786 & 31.786 & $31.755 .33^{\mathrm{a}} \pm 53,12$ \\
\hline Average \pm SD & $31.203^{\mathrm{a}} \pm 626$ & $31494^{a} \pm 586$ & $31648^{a} \pm 165$ & \\
\hline \multicolumn{5}{|c|}{ 5. Cost of gain (IDR/kg PBB) } \\
\hline Brahman & 17.076 & 17.725 & 17.517 & $17.438 .95^{\mathrm{a}} \pm 331,49$ \\
\hline Belmont Red & 18.361 & 16.656 & 15.567 & $16.861 .24^{\mathrm{a}} \pm 1.407,92$ \\
\hline Charolais & 18.656 & 17.007 & 15.567 & $17.076 .67^{\mathrm{a}} \pm 1.545,91$ \\
\hline Average \pm SD & $18030^{\mathrm{a}} \pm 840$ & $17129^{\mathrm{ab}} \pm 544$ & $16216^{\mathrm{b}} \pm 1125$ & \\
\hline
\end{tabular}

Description: unequal letters in rows show significant differences in $(\mathrm{P}<0.05)$, unequal letters in the columns show significant differences $(\mathrm{P}<0.05)$

\subsection{Feed Consumption}

Table 1 shows that fan usage has no significant effect $(p<0.05)$ on feed consumption with average value of $13.57 \mathrm{~kg} /$ head / day (pen with non fan), $13.69 \mathrm{~kg} /$ head / day (cage with blower fan) and $13.76 \mathrm{~kg}$ / head / day (enclosure with HVLS fan). It can also be seen that each cow has the same average value for Brahman 13,73 kg / head / day, Belmont Red $13,48 \mathrm{~kg} / \mathrm{head} /$ day and Charolais $13,81 \mathrm{~kg} / \mathrm{head} /$ day. Cattle reaction to temperature changes seen from the respiratory response and heart rate is a mechanism of the cow's body to reduce or release heat received from outside the body of the cattle. Increased heart rate is a response from the cattle body to spread the heat received into the cooler organs. Breathing is the response of the cattle body to remove or replace heat with the surrounding air. If these two responses do not succeed in reducing the extra heat from outside the body of the cattle, the temperature of the livestock organs will increase so that the cattle experience heat stress (Anderson .B. Pleasant, 1983).

The ongoing heat stress on cattle will have an impact on increased consumption of drinking water, decreased production, increased urine volume, and decreased feed intake. 


\subsection{ADG (Average Daily Gain)}

Table 1 shows that the use of enclosures with HVLS fans is an effective fan use of ADG growth in each breed of cattle with an average of $1.96 \mathrm{~kg} / \mathrm{heads} /$ day, blower fan average $1,85 \mathrm{~kg} / \mathrm{heads} /$ day and non-fan pen has an average of $1.74 \mathrm{~kg} / \mathrm{heads} /$ day for the cattle breed. Can also be seen in each cattle breed has the same average with the average value of each for Brahman $1.82 \mathrm{~kg} /$ heads/day, Belmont Red $1.86 \mathrm{~kg} /$ heads/day and Charolais 1.87 $\mathrm{kg} /$ heads/day.

\subsection{FCR (Feed Conversion Ratio)}

Table 1 shows that the use of non-fan enclosure is the most ineffective fan usage of the increase of FCR in each cattle breed with an average of 7.84, blower fan at 7,45 and the use of the pen with the most effective is HVLS fan with average of 7.05 for the cattle. In this table can also be seen in each cattle breed has the same average with the average value of each for Brahman 7.58, Belmont Red 7.33 and Charolais 7.43.

\subsection{Feed Cost}

Table 1 shows that fan usage for each cage has the same effect for each cattle breed on feed cost with 31,203,33 IDR/heads/day (control/non-fan) 31,494,67 IDR/heads/day (blower fan) 31,648 IDR/heads/day (HVLS fan). In this table can also be seen in each cattle breed has the same average with the average value for each Brahman 31,586.67 IDR/heads/day, Belmont Red 31.004 IDR/heads/day and Charolais 31.755,33 IDR/heads/day.

\subsection{Cost per Gain (Cost of Increase Weight Gain)}

Table 1 shows that the use of non-fan pen is the most ineffective usage of each cattle breed with 18.030.76 IDR/heads/day, blower at 17.129 IDR/heads/day and the most effective use of pen with HVLS fan has an average of 16.216.85 IDR/heads/day for the cattle. In this table can also be seen in each cattle breed has the same average with the average value of each for Brahman 17.438.95, IDR/heads/dayBelmont Red 16.861,24 IDR/heads/day and Charolais 17.076.67 IDR/heads/day.

\section{Conclusion}

There are some significant differences performance using Blower and HVLS fan with non using fan from belmont red and charolais, but there is no different with brahman with this treatment, there are big differenet in ADG, Cost of Gain and Feed Convertion Ratio (FCR). Using HVLS fan most effective performance and could make high margin than using blower fan and non using fan. So feedlotter has to use this method to optimize cattle performance, if they are import cattle with mostly european breed such as Belmont Red and Charolais, but you can also not using this method if you are import cattle with mostly brahman breed, because using this method not effective.

\section{References}


1. B. Pleasants dan R.A. Barton, Comparison of the carcass characteristics of steers of different breeds and pre-weaning environments slaughtered at 30 months of age. New Zealand Journal of Agricultural Research 40: 57- 68. (1997)

2. Aus-Meat, Aus-Meat Languange. 2nd Edition. (Aus-Meat, Sydney, 1987)

3. B. Brahmantiyo, Karkas, sifat fisik dan kimia daging tiga bangsa (Brahman, Angus dan Murray Grey). [Tesis]. Program Pasca sarjana. Institut Pertanian Bogor, Bogor (1996).

4. Blakkely dan Bade, Ilmu Peternakan 3rd Edition. Terjemahan: B. Srigandono dan Soedarsono, (Gajah Mada University Press, Yogyakarta, 1994)

5. B. Sarwono dan H. B. Arianto, Penggemukan Sapi Potong Secara Cepat (Penebar Swadaya, Jakarta, 2003)

6. B.S. Siregar, Penggemukan Sapi, (Penebar Swadaya, Jakarta, 2006). 